

Jiř́ Kupka ${ }^{\star *}$, Hana Švehláková1, Rostislav Poláček

${ }^{1}$ VSB-Technical University of Ostrava, Faculty of Mining and Geology 17. listopadu 15 St., 70833 Ostrava-Poruba, Czechia; 'jiri.kupka@vsb.cz

${ }^{2}$ Ministry of the Environment of the Czech Republic Vršovická 1442/65 St., 10010 Praha 10, Czechia

\title{
Selected environmental issues of the landscape of shale (Nízký Jeseník Mt., Czechia) - preliminary results
}

Introduction

For our purposes, we understand the environment as a set of natural, artificial and social components of the world that are (or may be) in direct contact with man. Natural components include, for example, climate, water and soil conditions. The artificial components can include buildings, production and transport facilities, communications and also terrain shapes such as mine heaps. Finally, social components include interpersonal relationships, culture, laws, economic conditions. The interaction between man and (his) environment then occurs in the landscape. The very content of the term landscape then has a very wide range, which can moreover be understood from various points of view. The landscape structure is variable over time and determined by its composition elements, which perform their own functions and are more or less dynamic. In the landscape we can distinguish the primary structure formed by the physical-geographic complex, i.e. natural elements such as geology, climate, water, natural terrain, etc. The secondary structure is the land use and material elements of this use (settlements, communications, mining remains, real vegetation cover, etc.). The tertiary structure of the landscape then includes intangible phenomena that can be reflected in the primary and secondary landscape structures. These include, for example, administrative units, ownership relationships, protection zones and regimes. The tertiary structure can also include the so-called magical places, which are connected with various legends and folklore traditions and the natural and artificial point of view. The primary, secondary and tertiary structure of the landscape is shaped by its typical character. An important landscaping agent are human activities.

The 'shale landscape' is a distinctive environmental and landscape phenomenon that can be seen from many points of view, as already mentioned above. It is located 


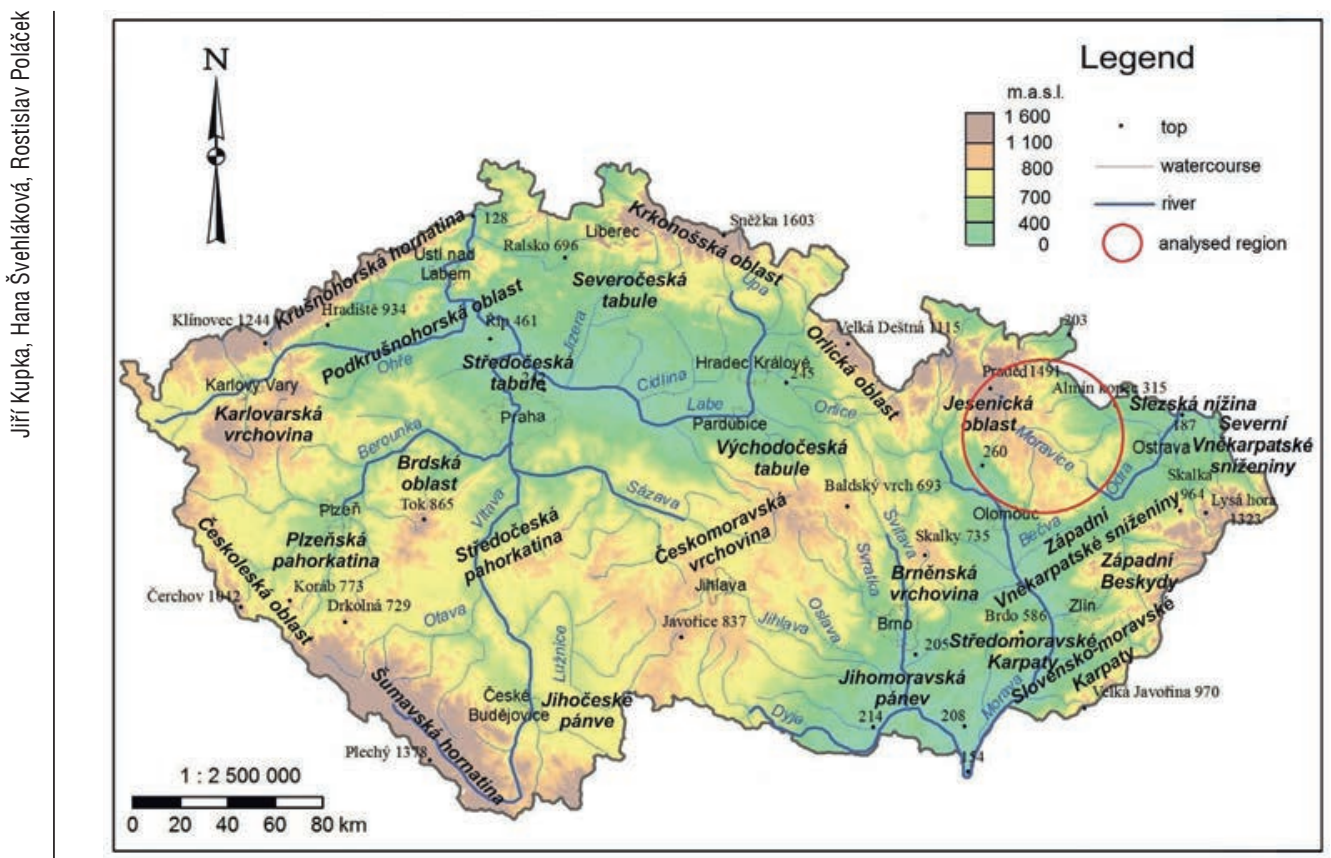

Fig. 1. Localisation of analysed region on map of Czechia (Source of map: Czech Environmental Information Agency - changed)

in the geomorphological unit Nízký Jeseník $(2.894$ km²) (Vencl, Strohalm, 2005). The mining of roofing shale tiles was concentrated in a part of the Lower Carboniferous of the Moravian-Silesian Region in terms of the geological division of the Bohemian Massif (Hrušecký, 1946; Zapletal et al., 1989) - Fig. 1. Here, for more than two centuries, shale mining has also left a distinct mark on local architecture and urbanism. With the resettlement of the original German-speaking population in 1945-1946, not only the roofing shale mining, but also the typical architectural elements that significantly contributed to the landscape character of the area were lost were reduced. Among these typical architectural features of the 'shale landscape' were, in particular, the original roofing - shale tiles attached with copper nails, which is now being replaced by another material or shale from import. The social composition of the population has also changed. New residents of abandoned settlements after the expulsion of Germans can be considered basically the first human colonisers of the territory. They began to transform the landscape and settlement structure, often without a deeper understanding of its specific dynamics and of course without following the ancestors traditions and respect to the genius loci.

We can characterise the 'shale landscape' as a post-industrial landscape; remnants of shale mining as landscape elements of post-industrial landscape. These include quarries and quarry lakes, adits and shafts, mine heaps and remnants of various build- 
ings. In total, these elements can be found in the cadastre of more than 50 villages and towns of Nízký Jeseník Mts. An interesting finding of recent decades is the fact that some habitats, which are traditionally perceived as a symbol of degradation of the natural environment (for example abandoned quarries or mine heaps), are inhabited by quite unique communities of plants and animals (Tropek, Rehounek, 2012). In the case of post-mining landscape, it is possible to speak of a biological colonisation, formed by plant and animal communities in various stages of succession and a cultural colonisation, formed by man and his activities.

The subject of our research is a comprehensive understanding of the landscape after shale mining, which includes the colonisation of landscape mining elements by plants, vegetation and animals, including humans.

\section{Material and methods}

The following text presents only some (most important) representatives of animals whose presence in the landscape after shale mining is related to post-mining landscape elements. The fauna survey started here in 2017 and can be divided into two phases. In the first phase, it is an inventory survey, which is focused especially on species protected, endangered or otherwise important from different taxonomic groups. In the second phase selected taxa (e.g. amphibians in quarry ponds, Hymenoptera insects on heaps or bats in underground spaces), the so-called specific zoological survey, are systematically studied.

Various types of methods were used in the inventory survey (observation, shearing using a hard skid net on islets of vegetation, individual collection in heaps of tailings material, etc.). They were in the underground in vertebrates and vertebrates studied by using conventional flashlights while browsing underground space each mine. In this way animals were examined in particular on the walls and ceilings (spiders, butterflies and bats). On the floor animals were surveyed under various objects (stones, remains of timbering, etc.). It was necessary in some taxa to take specimens for accurate determination. Animals were collected using entomological tweezers or exhauster, and fixed in $70 \%$ alcohol or killed by vapours of ethyl acetate. In the case of specific zoological research suitable methods were chosen for the study of individual taxa (e.g. aquatic animals net for amphibian studies, Mörick dish for Hymenoptera, bat-detector for bats).

The flora and vegetation survey was launched in 2017 with orientation terrain walks to find out the basic physiognomy of vegetation and the nature of the relief. In the first phase, an inventory survey was carried out focusing on rare and protected species according to Act no. 114/1992 Coll. and the corresponding red lists. Currently a phytosociological survey according to the rules of the Zurich - Montpellier School 
(Braun-Blanquet, 1964). In the flatter parts of the heaps, reléves had the shape of 100 $\mathrm{m}^{2}$ squares. On slopes, terraces and trailers, the shape of a rectangle was chosen as the more suitable one to maintain the recommended area. Phytosociological survey was performed at available slopes and exposures. Species were recorded in phytosociological tables during the season.

Due to the abundance of individual localities and sub-areas spread over a large area (including Jakartovice - 49 $54^{\prime} 54^{\prime \prime} \mathrm{N}, 17^{\circ} 41^{\prime} 3^{\prime \prime}$ E, surroundings of Hrubá voda -


$\mathrm{N}, 17^{\circ} 43^{\prime} 13^{\prime \prime}$ E, Zálužné - 49 $49^{\prime} 23^{\prime \prime} \mathrm{N}, 17^{\circ} 42^{\prime} 59^{\prime \prime}$ E and others), the phenomenon of 'colonisation' of shale landscape cannot be affected by tramps and campers but at least on the basis of some selected localities to describe the characteristics of this post-industrial colonisation and to outline issues that will be developed in the future. The existing survey is based primarily on published literature, including tramp texts and field research, which included both observation and documentation of informants' statements contacted on the spot and through links to well-known camp organisations in the Ostrava and Opava regions. In the future, it would be possible to use, for example, archival sources for individual localities.

\section{Preliminary results and discussion}

When anthropogenic activity is terminated or significantly reduced, natural processes will prevail and species with specific demands can be encountered at these post-industrial sites (sometimes at industrial sites), including a significant presence of rare and endangered species or the occurrence of organisms, which we consider to be unusual in our nature. In the Czech Republic, some species occur only at post-industrial sites. This is particularly so because post-industrial habitats create specific conditions that are typical to the present Central European landscape. Man has traditionally stopped farming in the landscape. Of course, the most common types of species are less demanding, common. However, in both cases, there are plants and animals that can find optimal conditions at post-industrial sites (Konvička et al., 2005).

Landscape elements after shale mining represent a varied mosaic of micro-sites in terms of both botanical and zoological aspects (Appendix 1A-B). For example, acidophilous grasses and sub-xerothermic plant species grow on the tops of mine heaps: Hieracium bauhini Schult. Asteraceae, Sedum acre L. Rosaceae and Potentilla argentea agg. L. Rosaceae. Some species, such as Chamaenerion palustre Scop. (= Epilobium dodonaei Vill.) Oenotheraceae, Filago arvensis L. Asteraceae or Lepidium campestre (L.) R. Br. Brassicaceae, are found directly on the mine heaps created by shale fragments. Some of these taxa belong to species from the red list of vascular plants in the Czech Republic. 
For the remains of buildings from indigenous peoples, we can see massive linden trees, or ornamental plants such as dwarf periwinkle (Vinca minor L.) Apocynaceae, Poet's narcissus (Narcissus poeticus L.) Amaryllidaceae, and yellow figwort (Scrophularia vernalis L.) Scrophulariaceae. There are endangered grass annual fescue (Vulpia myuros (L.) C. C. Gmel.) Poaceae on dry warm places and the most endangered species round-leaved wintergreen (Pyrola rotundifolia L.) Pyrolaceae on unstable, shaded areas of mine heaps.

From the animals, there is a xerothermal snake in the same places - the endangered smooth snake (Coronella austriaca Laur.) Colubridae, the endangered green tiger beetle (Cicindela campestris L.) Carabidae or rare spider Ozyptila claveata Walck Thomisidae (Appendix 1B). Adits represent a significant wintering ground for bats, for example Western barbastelle (Barbastella barbastellus Schreb.) Vespertilionidae or very abundant greater mouse-eared bat (Myotis myotis Borkh.) Vespertilionidae and lesser horseshoe bat (Rhinolophus hipposideros Bech.) Rhinolophidae. In flooded quarry lakes there is a rich population of critically endangered species European crayfish (Astacus astacus L.) Astacidae. Amphibians are represented by common toad (Bufo bufo L.) Bufonidae, smooth newt (Lissotriton vulgaris L. =Triturus vulgaris L.) Salamandridae, alpine newt (Ichthyosaura alpestris Laur. = Triturus alpestris Laur.) Salamandridae and common frog (Rana temporaria L.) Ranidae. Interesting findings include the finding of Niphargus tatrensis Wrześ. Niphargidae in the leachate of mining galleries. It follows from published and unpublished materials that after the expulsion of the original population, the colonisers of the above-mentioned elements of the mining landscape were campers followed by tramps who, unlike the new permanent residents, approached the landscape with respect and interest, based on the philosophy of the tramp movement. For example, the $44^{\text {th }}$ section of Junák in Ostrava had summer camp in Mokřinky near Melč - 49 $51^{\prime} 0^{\prime \prime} \mathrm{N}, 17^{\circ} 45^{\prime} 28^{\prime \prime} \mathrm{E}$, in 1947 (BVÚ, 2005). New, seemingly temporary and occasional 'residents' came to the country. The landscape features of the mining landscape have played and still play an important role in the life of campers and tramps as "colonisers". One of the possibilities to demonstrate this is the use of tramp toponyms and their spread. Some of the names refer directly to a particular landscape element (for example, a shaft with a tunnel called "Rodriguez's Tomb" on the cadastre of the defunct village of Nové Oldřunky - $49^{\circ} 45^{\prime} 4^{\prime \prime} \mathrm{N}, 17^{\circ} 40^{\prime} 38^{\prime \prime} \mathrm{E}$, or a quarry with a quarry pond ' $\mathrm{Na}$ špici' in Jakartovice), others include a wider area where several different mining elements are found (for example, a place called 'El Fuego' in the cadastre of the extinct Lesy). Sometimes a name given initially for only one particular landscape element was used for a much wider territory, as is the case with an abandoned quarry with a quarry pond in Jakartovice, which is named 'Horse Mine' and it functions under this name even in the mining register. 
Appropriately situated quarry, not flooded or flooded only in part, with various terraces and heaps, provided ideal conditions for establishing a permanent campsite. Often, such a 'romantic' place has become the goal of traditional clubs, and in some cases, the centre of group games. Quarry lakes themselves were attractive for the possibility of their exploration, bathing, or to build rafts and other simple vessels. The walls of operational and other buildings provided a suitable refuge after a minor modification (in some cases, the roof was made of shale tiles), fireplaces and sleeping bunk beds were built. Shale tiles served as 'guestbook sheets' for example to record visitor names or nicknames. From the shale itself were built camp circles and specific fireplaces (stacked to a height of $50 \mathrm{~cm}$ or more), various inscriptions visible from above, as well as towers and mounds. An important role was played by the fact that stay in these localities was not significantly regulated (Kupka, Pohunek, 2017).

\section{Conclusion}

The issues presented here are only a brief introduction to the wider elaborate of fauna, flora and vegetation of this region. Analysed colonisation processes, taking place in such a specific post-mining environment, should be considered in spontaneous and induced aspects. In the latter case, an important role is played by anthropopression of a different nature than it used to be, which is currently consequence of the increase in tourism in this area.

Acknowledgements

The research was co-funded by financial subsidy from the Student Grant Competition SP2018/15 "Selected environmental aspects of landscape after shale mining”.

\section{Conflict of interest}

The authors declare no conflict of interest related to this article.

References

BioLib https://www.biolib.cz/cz/taxon/ [In Czech]

BVÚ (2005). Kompas. Kompas TOM BVÚ 1945-2005 vydaný k 60. výročí založení oddílu, 65p.

Braun-Blanquet, J. (1964). Pflanzensoziologie: Grundzüge der Vegetationskunde. 3. Neubearb. und Wesentlich vermehrte Aufl. Wien: Apringer-Verlag. 631p. [In German]

de Jong, Y., Verbeek, M., Michelsen, V., Bjørn, P.P., Los, W., Steeman, F., Bailly, N., Basire, C., Chylarecki, P., Stloukal, E., Hagedorn, G., Wetzel, F.T., Glöckler, F., Kroupa, A., Korb, G., Hoffmann, A., Häuser, C., Kohlbecker, A., Müller, A., Güntsch, A., Stoev, P., Penev, L. (2014). Fauna Europaea - all European animal species on the web. Biodiversity Data Journal, 2, e4034. DOI: 10.3897/BDJ.2.e4034. https:// fauna-eu.org/

Konvička, M., Beneš, J., Čížek, L. (2005). Ohrožený hmyz nelesnich stanovišt: ochrana a management. Olomouc: Sagittaria, 127p. [In Czech]

Kupka, J., Pohunek, J. (2017). Krajina po těžbě břidlice očima trampio a táborníků aneb o brownfieldech jinak (Nízký Jeseník). Studia ethnologica pragensia. Univerzita Karlova, 2, 134-145. [In Czech] 
Tropek, R., Řehounek, J. (2012). Bezobratlí postindustriálních stanovišt: význam, ochrana a management. České Budějovice : ENTÚ BC AV ČR \& Calla, 2012. [In Czech]

Polish flora https://www.atlas-roslin.pl [In Polish]

Vencl, J., Strohalm, P. (2005). Novodobá těžba štípatelných břidlic v oblasti moravskoslezského kulmu. Současnost a perspektiva těžby a úpravy nerudních surovin 3, 321-328. Konferenční materiály V Konf. SPSTUNS. Ostrava. [In Czech]

Zapletal, J., Dvořák, J., Kumpera, O. (1989). Stratigrafická klasifikace kulmu Nízkého Jeseníku. Věstník Ústředního ústavu geologického, 64(4), 243-250. [In Czech]

Hrušecký, J. (1946). Dolování pokrývačských břidlic na severozápadní Moravě a ve Slezsku. Horník, 2, 44. [In Czech] 
Preliminary list of plant (A) and animal (B) species recorded in the habitats of the shale post-mining landscape (Jakartovice village $49^{\circ} 54^{\prime} 54^{\prime \prime} \mathrm{N}, 17^{\circ} 41^{\prime} 3^{\prime \prime} \mathrm{E}$ ):

Nomenclature of plants: according Polish flora (www.atlas-roslin.pl) and other Internet sources.

(A) Bryophytes: Abietinella abietina (Hedw.) M.Fleisch., Amblystegium serpens (Hedv.) Schimp., Atrichum undulatum (Hedw.) P.Beauv., Brachythecium rutabulum (Hedw.) Schimp., B. salebrosum (Hoffm. ex F.Weber et D.Mohr) Schimp., Brachytheciastrum velutinum (Hedw.) Ignatov et Huttunen (= Brachythecium velutinum W. P. Schimp.), Bryum argenteum Hedw., Ceratodon purpureus (Hedw.) Brid., Cynodontium polycarpon (Hedw.) Schimp., Dicranella heteromalla (Hedw.) Schimp., D. varia (Hedw.) Schimp., Dicranum polysetum Sw. ex anon., D. scoparium Hedw., Hylocomium splendens (Hedw.) Schimp., Hypnum cupressiforme Hedw., H. revolutum (Mitt.) Lindb., Lophocolea bidentata (L.) Dumort., Lophozia ventricosa (Dicks.) Dumort., Orthotrichum affine Schrad. ex Brid., O. anomalum Hedw., Oxyrrhynchium hians (Hedw.) Loeske (= Eurhynchium hians (Hedw.) Sande Lac.), Plagiomnium affine (Blandow ex Funck) T.J.Kop., Plagiothecium denticulatum (Hedw.) Schimp., P. succulentum (Wilson) Lindb., Pleurozium schreberi (Willd. ex Brid.) Mitt., Pohlia nutans (Hedw.) Lindb., Polytrichastrum formosum (Hedw.) G. L. Sm. (= Polytrichum formosum Hedw.), Polytrichum juniperinum Hedw., P. piliferum Hedw., Pseudoscleropodium purum (Limpr) M. Fleisch. ex Broth., Ptilidium ciliare (L.) Hampe, P. pulcherrimum (Weber) Vain., Racomitrium lanuginosum (Hedw.) Brid., Rhizomnium punctatum (Hedw.) T.J. Kop, Rhytidiadelphus squarrosus (Hedw.) Warnst., Rosulabryum laevifilum (Syed) Ochyra (= Bryum moravicum Podp.), Sanionia uncinata (Hedw.) Loeske, Scapania nemorea (L.) Grolle, Schistostega penata (Hedw.) F.Weber et D.Mohr, Syntrichia ruralis (Hedw.) F. Weber et D. Mohr (= Tortula ruralis (Hedw.) Gaertn., Meyer, \& Scherb.), Tortula muralis Hedw.

Vascular plants: Acer campestre L., A. platanoides L., A. pseudoplatanus L., Achillea millefolium L., Agrostis stolonifera L., Alnus glutinosa (L.) Gaertn., Anthriscus sylvestris (L.) Hoffm., Arenaria serpyllifolia L., Arrhenatherum elatius (L.) P. Beauv. ex J. Presl et C., Artemisia vulgaris L., Athyrium filix femina (L.) Rot, Betula pendula Roth, Bidens frondosa L., Bromus sterilis L., Calamagrostis epigejos (L.) Rot, Calystegia sepium (L.) R.Br., Carex praecox Schreb., Carpinus betulus L., Centaurea cyanus L., Cerasus avium (L.) Moench (= Prunus avium L.), Chamaenerion palustre Scop. (= Epilobium dodonaei Vill.), Chelidonium majus L., Chenopodium album agg., Cirsium arvense (L.) Scop., Conyza canadensis (L.) Cronquist, Cornus alba L. (= Swida alba (L.) Opiz), C. sanguinea L. (= Swida sanguinea Opiz), Corylus avellana L., Crataegus monogyna Jacq., Crepis biennis L., Daucus carota L., Digitaria sanguinalis (L.) Scop., Dryopteris 
filix-mas (L.) Schott, Echium vulgare L., Epilobium adenocaulon Hausskn. (= E. ciliatum Raf.), Erigeron annuus (L.) Pers., Eupatorium cannabinum L., Fagus sylvatica L., Festuca rubra L., Festuca sp., Filago arvensis L., Fragaria vesca L., Fraxinus excelsior L., Galeopsis pubescens Besser, G. speciosa Mill., Galium aparine L., Geranium robertianum L., Geum urbanum L., Glechoma hederacea L., Hedera helix L., Hieracium bauhini Schult., H. murorum L., H. sabaudum L., Hypericum maculatum Crantz, H. perforatum L., Impatiens parviflora DC., Inula conyza DC., Juglans regia L., Lepidium campestre (L.) R. Br., Ligustrum vulgare L., Malus domestica Borkh., Matricaria perforata Mérat (= Tripleurospermum inodorum (L.) Sch. Bip.), Melandrium album (Mill.) Garcke (= Silene latifolia Poir.), Mycelis muralis (L.) Dumort., Myosotis sylvatica Ehrh. ex Hoffm., Oenothera biennis L., Oxalis acetosella L., Padus avium Mill. (= Prunus padus L.), Pastinaca sativa L., Picea abies (L.) H.Karst., Picris hieracioides L., Pinus nigra J.F. Arnold, P. sylvestris L., Poa compessa L., P. pratensis L., Populus tremula L., Potentilla argentea agg. L., P. erecta (L.) Raeusch., Prunus spinosa L., Pyrola rotundifolia L., Quercus robur L., Ribes uva-crispa L. (= Grossularia uva-crispa (L.) Mill.), Robinia pseudacacia L., Rosa sect. caninae DC., Rubus caesius L., R. idaeus L., Rumex acetosa L., R. acetosella L., R. obtusifolius L., Salix caprea L., S. purpurea L., Sambucus nigra L., Scrophularia vernalis L., Senecio jacobaea L., S. ovatus (P. Gaertn., B. Mey. et Scherb.) Willd., S. vulgaris L., Solidago canadensis L., S. gigantea Aiton, Sorbus aucuparia L. em. Hedl., Stellaria graminea L., S. media (L.) Vill., Symphytum officinale L., Tanacetum parthenium (L.) Sch. Bip., Taraxacum sect. ruderalia Kirsch., H.Øllg. \& Štěpánek, Tilia cordata Mill., T. platyphyllos Scop., Urtica dioica L., Verbascum thapsus L., Veronica chamaedrys L., Viola odorata L., Vulpia myuros (L.) C. C. Gmel.

Nomenclature of animals: according BioLib (https://www.biolib.cz/cz/taxon/), Fauna Europaea (https://fauna-eu.org/) and other Internet sources.

(B) Snails: Aegopinella nitens Mich. (= Hyalinia nitens Mich.), Alinda biplicata Mont. (= Balea biplicata Mont.), Arion distinctus J. Mabil., Arion vulgaris Moquin-Tand., Boettgerilla pallens Simr., Cochlicopa lubrica O. F. Müll., Deroceras agreste L., D. reticulatum O. F. Müll., Discus rotundatus O. F. Müll., Helix pomatia L., Limax cinereoniger Wolf, Monachoides incarnatus O. F. Müll., Oxychillus glaber Rossm., Radix labiata Rossm.

Crustaceans: Armadillidium vulgare Latre., Astacus astacus L., Ligidium hypnorum Cuv., Niphargus tatrensis Wrześ., Oniscus asellus L., Porcellio scaber Latre.

Spiders: Amaurobius fenestralis Ström, Cicurina cicur Fabr., Coelotes pabulator Sim. (= C. terretris Wild.), Drassyllus praeficus L. Koch, Meta menardi Latre., Ozyptila claveata Walck., Pirata hygrophilus Thor., Pisaura mirabilis Cler.

Grasshoppers and crickets: Pseudochorthippus parallelus Zetter. (= Chorthippus parallelus Zetter.), Gomphocerippus rufus L., Oedipoda caerulescens L., Phaneroptera falcata Poda, Pholidoptera griseoaptera De Geer, Tetrix subulata L., Tettigonia cantans Fuess. 
Butterflies and moths: Aglais urticae L., Anthocharis cardamines L., Apatura ilia Denis \& Schiff., Aphantopus hyperantus L., Araschnia levana L., Argynnis paphia L., Autographa gamma L., Coenonympha pamphilus L., Colias hyale L., Gonepteryx rhamni L., Inachis io L. (= Aglais io L.), Lasiommata megera L., Leptidea reali Reiss., Lycaena dispar Haw., Maniola jurtina L., Melanargia galathea L., Nymphalis antiopa L., Pararge aegeria L., Pieris brassicae L., P. napi L., P. rapae L., Polygonia c-album L., Polyommatus icarus Rottem., Scoliopteryx libatrix L., Thymelicus lineola Ochsen., Triphosa dubitata L., Vanessa atalanta L., V. cardui L.

Beetles: Cantharis rustica Fall., Carabus violaceus L., Chrysomela fastuosa Scop., Cicindela campestris L., Anoplotrupes stercorosus Scri. (=Geotrupes stercorosus L.), Leptura quadrifasciata L., Nicrophorus vespillo L., Oiceoptoma thoracicum L., Phosphuga atrata L., Psyllobora vigintiduopunctata L., Rhagonycha fulva Scop., Silpha obscura L., Staphylinus caesareus Cederh., Tachyura parvula Deje., Thanatophilus rugosus L.

Hymenoptera: Agenioideus cinctellus Spin., Ammophila sabulosa L., Andrena fulva Müll., Andrena haemorrhoa Fabr., A. minutula Kir., A. nigroaenea Kir., A. nitida Müll., A. strohmella Stöck., A. varians Kir., Anoplius infuscatus Van der Lind., Apis mellifera L., Arachnospila anceps Wesm., Bombus campestris Panz., B. pascuorum Scop., B. rupestris Fabr., B. terrestris L., Halictus maculatus Smith, H. tumulorum L., Hylaeus signatus Panz., Lasioglossum calceatum Scop., L. morio Fabr., L. pauxillum Schen., Melecta albifrons Foer., Nomada conjungens Herrich-Schäf., N. flavoguttata Kir., N. fulvicornis Fabr., N. succincta Panz., Osmia bicornis L., Polistes nimpha Christ, Priocnemis perturbator Harr., Rhopalum clavipes L., Sphecodes gibbus L., Trypoxylon minus Beaum., Vespula germanica Fabr., V. vulgaris L.

Amphibians: Bufo bufo L., Ichthyosaura alpestris Laur. (=Triturus alpestris Laur.), Lissotriton vulgaris L. (= Triturus vulgaris L.), Pelophylax esculentus L., Rana temporaria L.

Reptiles: Anguis fragilis L., Coronella austriaca Laur., Lacerta agilis L., Natrix natrix L.

Bats: Barbastella barbastellus Schreb., Myotis emarginatus É. Geoff., M. myotis Borkh., M. mystacinus Kuhl, M. nattereri Kuhl, Plecotus auritus L., Rhinolophus hipposideros Bech. 


\begin{abstract}
The area of the Nízký Jeseník Mts. is, among other things, well known for its shale roofing tiles since the 18th century. In places where shale was intensively or extensively exploited until 1945, abandoned areas after mining works remained. In general, every mining is perceived as a activity of landscape degradation by the public. However, these indelible traces of shale mining in the form of various mining-related objects (e.g. abandoned quarries, quarry ponds, shafts, drains etc.) are also gradually becoming places that are colonized by unique plant and animal communities. There are very interesting species bond to specific environmental conditions of post-mining landscape, with frequent rare and endangered species. People have also become 'new' colonisers in the case of the shale landscape.
\end{abstract}

Key words: post-industrial landscape, abandoned quarries, mine heaps, fauna colonisation, vegetation colonisation, cultural colonisation

Received: [2019.09.05]

Accepted: [2019.11.19]

Wybrane zagadnienia środowiskowe krajobrazu łupków ilastych (Nízký Jeseník, Czechy) - wstępne rezultaty

Streszczenie

Obszar gór Niskiego Jesionika znany jest od XVIII wieku, m.in. z łupków dachówkowych. W miejscach, w których łupek był intensywnie lub ekstensywnie eksploatowany do 1945 r., pozostały wyrobiska górnicze. Generalnie, każda działalność wydobywcza jest postrzegana przez społeczeństwo jako działanie degradujące krajobraz. Jednak te nieusuwalne ślady wydobycia łupków ilastych, w postaci różnych obiektów związanych z górnictwem, np. opuszczone kamieniołomy, stawy kamieniołomowe, szyby, dreny itp., również stopniowo stają się miejscami kolonizowanymi przez unikalne ugrupowania roślin i zwierząt. Interesujące gatunki wiążą się ze specyficznymi warunkami środowiskowymi krajobrazu pogórniczego, a często występują tam gatunki rzadkie i zagrożone. W przypadku krajobrazu łupkowego, także sami ludzie stali się „nowymi” kolonizatorami.

Słowa kluczowe: krajobraz poprzemysłowy, opuszczone kamieniołomy, hałdy min, kolonizacja fauny, kolonizacja roślinności, kolonizacja kulturowa

\title{
Information about authors
}

\section{Jiř́ Kupka}

The author is focusing on ecological and environmental applications in post-industrial landscape (especially fauna study at post mining sites, including underground spaces), biological researches related to biogeochemistry and environmental geochemistry, brownfields reuse and didactics of natural sciences.

\section{Hana Švehláková}

The author is a geobotanist with a focus on plant communities affected by industry and coal mining. She also deals with the relationship between soil seed bank and above-ground vegetation and the spread of invasive plant species in the post-mining landscape.

\section{Rostislav Poláček}

The author is engaged in research of Hymenoptera insects with a focus on wasps, bumble bees and solitary bees in post-industrial landscape. The research is carried out mainly at localities (heaps) after mining of mineral resources. 